\title{
Pontos de contato entre o pensamento antropológico e teatral
}

\author{
RichARD SCHECHNER \\ tradução: ANA LETícia DE FIORI \\ revisão técnica: John Cowart Dawsey, Diana Paola Gómez Mateus
}

Quer os praticantes e acadêmicos de ambas as disciplinas gostem ou não, há pontos de contato entre a antropologia e o teatro: e provavelmente há mais pontos surgindo. Estes pontos de contato são até o momento seletivos - apenas um pouco da antropologia toca um pouco do teatro. Mas quantidade não é a única, ou mesmo a mais importante, medida de fertilidade conceitual. Esta mistura vai, penso eu, ser frutífera. Clifford Geertz escreve que "nos anos recentes houve uma enorme quantidade de mistura de gêneros na ciência social, assim como na vida intelectual de modo geral" $(1980,165)$. Ele se dirige à explicar a "analogia do drama" como uma das maiores tendências no pensamento antropológico. A analogia foi desenvolvida principalmente por meio e aos cuidados de Victor Turner, que via o conflito social seguir a estrutura do drama e adaptar sua disposição subjuntiva "como se". A obra de Turner se encaixa satisfatoriamente com a de Erving Goffman, que, ao nível da cena e do "personagem" (quem está sendo, ou fingindo ser, quem), encontrou teatro em toda parte da vida cotidiana.

Mas, e quanto aos contatos feitos da outra direção, das várias artes performáticas? São estes contatos que eu conheço um pouco a partir do meu trabalho domo diretor de teatro. E é neles que eu irei me concentrar aqui.

Até que ponto os performers de rituais - os dançarinos cervos dos yaquis do Arizona ou os xamãs coreanos (para nomear apenas dois grupos sobre os quais eu tenho informação di- reta) - estấo conscientes dos aspectos de artes performáticas de seu trabalho sagrado? E o que dizer acerca dos eventos performativos em larga escala que não podem ser facilmente classificados como pertencendo seja ao ritual, ao teatro ou à política? Eu estou falando de performances como as Ramlilas do norte da Índia (ver capítulo 4$)^{1}$ e as peças da paixão dos TảZiyeh do Irã. O contato é uma operação de mão única ou mesmo de mão dupla? Alguns antropólogos, com Turner em sua dianteira, começaram a "performatizar antropologia" (Turner e Turner, 1982); e algumas pessoas do teatro, Peter Brook, Jerzy Grotowski, e Eugenio Barba em especial, exploraram o que Barba chama de "antropologia teatral” (Barba 1980, 1981, 1982a). Antes de examinar estes exemplos concretos, eu discutirei cada um dos seis pontos de contato.

\section{Transformaçáo do Ser e/ou Consciência}

Seja permanentemente, como em ritos iniciáticos, ou temporariamente, como no teatro estético ou em danças em transe, os performers - e algumas vezes os espectadores também sáo alterados pela atividade de performatizar. Como uma transformaçáo permanente ou uma transformação temporária é atingida? Olivier fazendo o papel de Otelo é diferente de um ator nô performatizando a máscara de Benkei ou um dançarino Sanghyang balinês em tran- 
se? Há alguma diferença real de significado entre os vários termos que diferentes culturas imaginaram para descrever o que os performers fazem? Pode a transformação da consciência durante a performance ser medida ao nível da atividade cerebral?

Enquanto observava a dança das renas dos yaquis do Arizona em novembro de 1981, eu me perguntei se a figura que eu via era um homem e um cervo simultaneamente; ou, para dizer isso de um modo que um performer possa entender, colocar a máscara de cervo fazia do homem "não um homem" e "não um cervo", mas algum lugar entre. $\mathrm{O}$ topo de sua cabeça (do homem/do cervo), com seus chifres e máscara de cervo, é um cervo; a parte de sua cabeça abaixo do pano branco, com seus olhos de homem, nariz e boca, é um homem. O pano branco que o dançarino fica ajustando é a fisicalização da impossibilidade de uma transformação completa em um cervo. Nos momentos em que o dançarino é um "não eu" e contudo um "não não eu", sua própria identidade, e aquela do cervo, é localizável apenas nas áreas liminais da "caracterização", "representação", "imitação", "transportação" e "transformação" (ver capítulo 3). Cada uma dessas palavras diz que os performers não podem dizer quem eles são. Únicos entre os animais, os humanos carregam e expressam identidades múltiplas e ambivalentes simultaneamente.

Aqueles entre os yaquis observando a dança do cervo sentem que um ser vindo do buya aniya ("mundo floral"), o mundo dos seres selvagens e livres, temporariamente entrou no mundo humano - não exatamente um ser capturado, mas um ser que consentiu em fazer uma visita. Isto não é tão diferente daquilo que os balineses sentem sobre deuses e espíritos que "descem" para possuir dançarinos em transe. Seja como for conceitualmente, as técnicas de "chegar lá", de preparar o performer para performatizar, são em grande parte as mesmas para o dançarino cervo e para o dançarino do transe balinês ou para um ator interpretando um papel em Nova Iorque: observação, prática, imitação, correção, repetição.

Ao mesmo tempo, pode-se notar que quando um "forasteiro" aprende a dança do cervo, ou uma versão disso, os próprios yaquis encaram esta dança de modo muito diferente de quando fazem sua própria dança do cervo. O Balé Folclórico Mexicano tem um número chamado "Dança do Cervo", Anselmo Valencia, líder ritual dos yaquis de Nova Pascua, Arizona, diz o seguinte sobre o Balé Folclórico:

Valencia: As pessoas que reuniram esta companhia mexicana estavam praticando várias danças culturais de muitas partes do Mexico - qualquer um pode aprender a dança, e eles aprenderam. Então eles trouxeram uma imitação bastante ampla da dança do cervo.

Questão: Como os yaquis que assistiram, e que sabiam como dançar o cervo, sentiram-se?

Valencia: Muito, muito desencorajados. De fato, um dos jovens homens que se tornou um dançarino de cervo estava em treinamento naquele momento para o exército e ele viu a dança no México. Ele estava muito desencorajado e ele disse: "Você sabe, eles apenas estão fazendo os yaquis de bobos". Eu disse a ele, não veja as coisas desse modo. Veja como uma peça. Não há nada religioso nisso, nada indígena nisso. É para a população não-indígena. Não é uma performance yaqui.

Questão: As coisas no Folclórico são diferentes da dança que assistimos ontem?

Valencia: Tudo é diferente. A cabeça do cervo é diferente, o passo é diferente. Isso não nos agride, isso nos frustra. Então nosso povo deixou de fazer isso. É frustrante quando alguém diz "eu estou fazendo uma coisa yaqui" quando os yaquis sabem que não é. $(1981,4)$

Valencia também contou sobre as velhas canções de cervo que foram gravadas e vendi- 
das. As velhas canções tinham sido "muito boas por centenas e centenas de anos", mas "gravar os mistérios de tais cançóes de cervo retirou os poderes espirituais dessas canções” e as pessoas pararam de cantá-las.

Valencia: Se uma centena de cançôes fossem gravadas, e uma centena de cançóes fossem vendidas, eu acho que nós não as usaríamos mais. Não é a condiçáo de "novidade". Você tem que ser um yaqui, ou pelo menos um índio, para entender como os mistérios daquela canção - as palavras, o seu propósito, o seu propósito espiritual - para entender que os benefícios espirituais da canção são retirados são retirados se a canção é comercializada. (1981, p. 4-5)

Atualmente, em grande parte graças à liderança de Valencia, as canções e danças estão sendo restabelecidas aos yaquis. O ponto notável é que estas performances não tem uma vida independente: elas estão ligadas à audiência que as ouve, ao espectador que as assiste. A força da performance está na relação muito específica entre os performers e aqueles-para-quem-a-performance-existe. Quando vem a audiência consumidora, os "poderes espirituais" se vão.

As transformaçóes do ser que compóem a realidade da performance evidenciam a si mesmos em todo tipo de anacronismos e combinaçóes estranhas e incongruentes que refletem as qualidades liminais da performance. $\mathrm{O}$ fato do tambor de água do cantor cervo ser colocado em uma moderna panela de metal , tirada diretamente da cozinha ao lado para o galpão da dança não é apenas uma questão de modernização, de aproveitamento de recursos disponíveis (pelo que os performers são famosos em todo o mundo), mas um exemplo de duplicação transformadora. A panela de cozinha é análoga ao dançarino e seus cantores: a panela não deixa de ser ela mesma quando serve para evocar o mundo floral das canções do cervo. Tanto a panela quanto os performers são “não eles" e "não não eles". Panela e performer conectam dois reinos da experiência, os únicos dois reinos com os quais a performance lida: o mundo da existência contingente como objetos e pessoas comuns e o mundo da existência transcendental como implementos mágicos, deuses, demônios, personagens. Não é que um performer deixa de ser ela ou ele mesmo quando ela ou ele se tornam outros - eus múltiplos coexistindo em uma tensão dialética não resolvida. Assim como um marionete não deixa de ser "morto" quando é animado, o performer não deixa de ser, em algum nível, seu eu comum quando ele é possuído por um deus ou interpreta o papel de Ofélia. Mesmo Stanislavski - cuja obra suporta o mais sistemático naturalismo - disse:

Nunca se perca no palco. Sempre aja dentro de sua própria pessoa, como um artista. Você não pode jamais fugir de si mesmo. O momento em que você se perde no palco, você deixa de viver verdadeiramente seu papel e da inicio a uma atuação falsa e exagerada. (1946, p. 167)

Os balineses dizem que uma pessoa que machuca a si mesma durante o transe está fingindo.

A beleza da "consciência performática" é que ela ativa alternativas: "isto" e "aquilo" estáo ambos simultaneamente operativos. $\mathrm{Na}$ vida ordinária as pessoas cumprem destinos - tudo parece predeterminado: há uma chance remota de dizer: "Corte, refaça isso". Mas a consciência performática é subjuntiva, cheia de alternativas e potencialidade. Durante os ensaios especialmente, alternativas são mantidas vivas, o trabalho é intencionalmente não fixado. A celebraçáo da contingência - um triunfo verdadeiro, se temporário, sobre a morte e o destino - descreve mesmo as performances rituais, especialmente aqueles rituais conduzidos por velhos mestres a quem a habilidade de improvisar não é negada.

Este mesmo princípio performativo se aplica ao drama nô e é visível lá na máscara que é mui- 
to pequena para o rosto do ator - muito pequena, quer dizer, se a intenção fosse que a máscara cobrisse todo o rosto (como o faz no Ramlila). No teatro nô, sob a delicada máscara branca da jovem feminina o espectador enxerga o queixo largo e escuro de um maduro performer masculino. A formalidade extrema do nô não deixa dúvidas de que a dupla exposição não é um acidente. Porque parte do rosto do ator principal é deixada à mostra - e portanto subvertendo a própria ilusão que a máscara e a fantasia criam? O encanto do nô não aumenta com o conhecimento de que uma transformação incompleta é alcançada?

Zeami, instruindo o shite do nô no século $\mathrm{XV}$ em como treinar e performar, enfatiza a tensão dialética entre tai e $y u$, literalmente "o que é visto pela mente" (tai) e "o que é visto pelos olhos" (yu). Recentemente, Tatsuro Ishii investigou os últimos escritos de Zeami nos quais estas ideias estão expressas.

Zeami não define explicitamente tai e yu em um sentido moderno, mas tai pode ser interpretado como uma textura fundamental na atuação dependente da mente de um performer, e yu é a manifestação externa, visual... Copie tai, e ele se tornará yu... Se uma pessoa copia yu, este se tornará um falso tai, e ela não poderá ter nem tai nem yu... A ideia de tai e yu nos lembra de outro axioma bem definido referente à atuação, fornecido pelo Kayko (de Zeami): "Mova sua mente cem por cento e seu corpo setenta por cento" (1982, p. 8-9).

Como muitas das instruçóes dadas ao ator tanto em tradiçóes euroamericanas quanto nas asiáticas - uma recomendação aparentemente simples é, na prática, complexa. Pois diz-se que o tai do nô não reside materialmente no ator, e sim na máscara que é nitidamente visível; e o yu do nô está no queixo vivo revelado por trás da máscara mas em grande parte oculto por ela. $\mathrm{O}$ trabalho do shite é tornar completamente manifesto o tai da máscara: isto é feito não apenas vestindo a máscara ou animando-a ativamente, mas rendendo-se a ela, abolindo seu próprio yu. Este tipo de trabalho não é tão diferente do que Grotowski - influenciado pelas formas asiáticas, especialmente yoga e kathakali - cobrava de seus performers.

Para o ator mediano o teatro é em primeiro lugar e principalmente ele mesmo, e não o que ele está apto para alcançar por meio de sua técnica artística... Tal atitude alimenta o despudor e a autossatisfação que fazem com que ele apresente atos que não demandam nenhum conhecimento especial, que são banais e da ordem do lugar comum... O ator que empreende um ato de autopenetraçáo, que revela a si mesmo e sacrifica a parte mais interior de si mesmo - a mais dolorosa, que não se destina aos olhos do mundo - deve ser capaz de manifestar o menor impulso. Ele deve ser capaz de expressar, por meio de som e movimento, aqueles impulsos que ondulam na beira entre o sonho e a realidade (1968, p. 29,35).

Tanto Grotowski quanto Zeami exigem do ator anos de treinamento. Obter os meios de manifestar o tai é equivalente ao que Grotowski chama de "sacrifício [da] parte mais interior de si” do ator.

Em ambos os casos o ator passa por mudanças profundas, até permanentes, na consciência. É muito importante notar, considerando o estado da cultura euroamericana no final do século XX, que enquanto o programa de Zeami tem estado em vigor por mais de quatrocentos anos, sendo passado de pai para filho entre várias famílias de shites do nô, a fase do "teatro pobre" de Grotowski, que produziu magistrais produçóes como O Príncipe Constante, Akropolis e Apocalypsis cum Figuris não durou mais que dez anos, até por volta de 1969. Foi como se o projeto de Grotowski não pudesse encontrar 
os meios de continuar porque a consciência pessoal que evocava e demandava continuamente era demasiado exigente, seu sistema rigoroso de treinamento não sendo compatível com o individualismo-narcisismo euroamericano.

Brecht, como Zeami, Stanislavski e Grotowski, enfatiza as possibilidades criativas do tipo de transformação incompleto e problemático pelo qual passa o performer.

O ator [diz Brecht] não permite a si mesmo ser completamente transformado no palco no personagem que ele está retratando. Ele não é Lear, Harpagon, Schweik: ele os mostra. Ele reproduz suas observaçóes táo autenticamente quanto puder; ele oferece seu modo de comportamento no melhor de suas habilidades e conhecimento dos homens; mas ele nunca tenta persuadir a si mesmo (e portanto os outros) que isto corresponde a uma transformação completa (1964, p. 137).

A distância entre o personagem e o performer permite que se insira um comentário; para Brecht este era muito frequentemente um comentário político, mas poderia ser também como o é para os dançarinos pós-modernos e os artistas de performance - um comentário estético ou pessoal. Brecht encontrou o tipo de atuação que ele desejava no teatro chinês. Indicando as dificuldades que atores europeus tinham em "tornar-se" seus papeis, noite após noite, Brecht diz "Estes problemas são desconhecidos para o performer chinês, pois ele rejeita a conversão completa. Ele limita a si mesmo desde o início a simplesmente citar o personagem interpretado. Mas com que arte ele o faz!” (1964, p. 94). Assim Brecht, como outros mestres diretores-performers, enfatiza as técnicas necessárias para este tipo de atuação: atuação na qual a transformação da consciência não é apenas intencionalmente incompleta mas também revelada como tal aos espectadores, cujo deleite está na dialética não resolvida.
Desnecessário dizer que este não é o único tipo de atuação. O trabalho de Stanislavski, especialmente como foi elaborado nos EUA, forma a base para o naturalismo que busca esconder todo o artifício. Este é o estilo dominante nos filmes e televisão norteamericana. Se não dominante, está fortemente presente no teatro norteamericano. E há vários lugares nos quais se pretende promover uma transformação total das consciências por meio do transe, máscaras para o rosto e o corpo, e outras técnicas performativas. Estas transformações são em maioria temporárias - eu as chamo "transportações" (veja o capítulo 3). O que é interessante é que quanto mais maduro, habilidoso e respeitado o performer, mais provavelmente ela ou ele praticará uma transformação incompleta ou não resolvida.

Uma questão corolária que pode a partir de uma investigação completa provar ser a chave para o problema da transformação da consciência, é o que exatamente se espera da audiência. Eles devem assistir à distância e julgar, como Brecht desejou que sua audiência fizesse? Ou eles devem ser tragados pela performance, respondendo com tal intensidade - como em algumas igrejas que eu frequentei em Nova Iorque - que durante o auge do serviço todos, ou quase todos, estão performatizando? Entre estes extremos quase todo tipo de conduta e participação pode ser encontrado. Ao longo do continuum, diferentes tipos de atenção são exigidos dos espectadores - e diferentes tipos de transformação da consciência dentro dos performers. Assim, há uma grande variedade de transformaçôes de consciência envolvidas: junto aos performers individuais, junto ao grupo performático, junto à audiência como indivíduos e como grupo - e entre estas entidades.

\section{Intensidade da performance}

Em todos os tipos de performance uma certa fronteira definida é cruzada. E se não é, a per- 
formance falha. Quando eu dirigia The Performance Group (1967-80), críticas ruins às vezes combinadas com um clima ruim ou falta de dinheiro para propaganda faziam com que muito pouca gente fosse ao teatro. Em várias ocasióes os membros do TPG discutiram um pouco antes de uma performance marcada se de fato o "show deveria continuar". Como um princípio básico, decidimos que se os performers estivessem em maior número que a audiência, o show seria cancelado. Porque a menos que houvessem espectadores suficientes para animar o teatro um teatro ambiental, imagine, no qual os performers estão conscientes da audiência, no qual o espaço é compartilhado e trazido à vida pela interação entre performers e espectadores - o próprio show careceria de fermento vivo e náo cresceria. Nenhuma performance teatral funciona desligada de sua audiência. Claro, teatro e dança (seja estética ou ritual) que precisam da participação da audiência são mais dependentes da audiência do que eventos nos quais o papel do espectador é o de receptor passivo. Mas mesmo quando aparentemente passivo, como em um concerto de música clássica ou numa performance do Racine, uma casa cheia ansiosa pela performance, para comparecer ao trabalho desse artista em particular, literalmente levanta um elenco de artistas, propele-os e os sustenta.

Os espectadores são bastante cientes do momento em que uma performance decola. Uma "presença" se manifesta, algo "aconteceu". Os performers tocaram e comoveram a audiência, e algum tipo de colaboração, de vida teatral especial e coletiva, nasce. Esta intensidade da performance - e eu, pessoalmente, não creio que o mesmo tipo de coisa pode acontecer com filmes ou televisão, cujo forte é afetar pessoas individualmente mas não gerar energias coletivas -foi chamado de fluxo por Mihaly Csikzentmihalyi (1975, p. 35-36).

Performances reúnem suas energias quase como se o tempo e o ritmo fossem coisas con- cretas, físicas, flexíveis. Tempo e ritmo podem ser usados do mesmo modo que texto, objetos cênicos, fantasias, e os corpos dos performers e audiência. Uma grande performance modula intervalos de som e silêncio, a densidade crescente e decrescente de eventos temporal, especial, emocional e cinestesicamente. Estes elementos estão costurados em um padrão aparentemente inevitável e complicado (embora percebido como simples). Este "fluxo" ocorre mesmo em performances que náo constroem um clímax do modo que o culto de uma igreja pentecostal ou uma performance de Morte de um Caixeiro Viajante ou Macbeth fariam. Por exemplo, os dervixes rodopiantes da Turquia, ou as danças pós-modernas rodopiantes de Laura Dean, ou os movimentos excruciantemente lentos, espremidos por um período de horas, de Deafman Glance ou Einstein on the Beach de Robert Wilson, desenvolveram padrões de intensidades que se acumulavam, ou mesmo aceleravam. De fato, a dançarina Trisha Brown chama alguns de seus trabalhos mais poderosos "acumulaçôes". "Uma acumulação é um procedimento aditivo no qual o movimento 1 é apresentado; e recomeça. O movimento 1; 2 é adicionado e recomeça. 1; 2; 3 é adicionado e recomeça, etc. até que a dança acabe" (1975, p. 29).

Performances como as de Dean, Brown e dos dervixes não atingem um clímax; a acumulação-repetição ergue os performers, e frequentemente os espectadores também, em um transe extático. Em uma acumulação, como em música repetitiva como a de Philip Glass, a mente do espectador sintoniza em variaçóes sutis que não seriam detectáveis em uma estrutura na qual a atenção é dirigida para o desenvolvimento melódico ou narrativo. Muitas vezes eu organizei "danças noite adentro" para mostrar o poder da acumulação e repetição. Grupos de oito a vinte e cinco pessoas dançavam em um simples círculo anti-horário entre quatro e oito horas. Porque anti-horário? Pode ter a ver com as diferenças 
entre o cérebro direito e o esquerdo. Toda vez que eu participei deste tipo de dança eu tive, e outros também tiveram, uma experiência semelhante ao transe, uma experiência de fluxo total na qual por períodos variáveis o senso de mim como um indivíduo, a quantidade de tempo passando, a consciência do ambiente no qual eu estava (a céu aberto em um campo ou dentro de um ginásio, para mencionar dois) foram abolidos. O que sobrou foi um senso vago rememorável de mover-se em círculos e a sensação de outras pessoas, de outros corpos, de cada um dos meus lados. Este tipo de experiência eu descrevi como "intensidade totalmente baixa", como distinto do que me aconteceu nas igrejas pentecostais ou no festival de matança de porcos nas terras altas de Papua Nova Guiné onde eu experimentei uma "intensidade totalmente alta" (ver Schechner, 1977, p. 63-98). Em ambos os casos meu sentido de mim como Richard Schechner se dissolveu. Intensidades totalmente baixas são trofotrópicas: o batimento cardíaco desacelera, assim como a pressão sanguínea; as pupilas estão constritas, a EEG é sincronizada. Há uma tendência em direção ao transe e à sonolência. Intensidades totalmente altas são ergotrópicas: o batimento cardíaco aumenta, assim como a pressão sanguínea; as pupilas se dilatam, a EEG é dessincronizada. Há um alto nível de excitação e despertar. Para uma discussão completa desses estados ver Lex 1979.

Compreender a "intensidade da performance" é descobrir como uma performance constrói, acumula, ou usa a monotonia; como ela atrai participantes ou intencionalmente os barra; como o espaço é projetado ou manipulado; como o cenário ou roteiro é usado - em resumo, um exame detalhado de todo o texto performático. Mais ainda, é um exame das experiências e açóes de todos os participantes, do diretor à criança dormindo na audiência.

A dança do cervo em Nova Pascua parece seguir um padrão de intensidade com oito fases. A dança se movia de um início lento para um final muito rápido de alta intensidade seguida por uma interrupção abrupta e depois começando novamente. Este padrão é análogo ao jo-ha-kyu da estética japonesa.

A expressão do jo-ha-kyu representa as três fases nas quais se subdivide a ação do ator. A primeira fase é determinada pela oposição entre a força que tende a crescer e outra que a retém (jo = reter); a segunda fase (ha $=$ romper) ocorre no momento em que se libera dessa força até que se alcança a terceira fase $(\mathrm{kyu}=$ rapidez$)$ na qual a ação alcança sua culminância, usando toda a sua força para parar subitamente quando se coloca frente a frente com um obstáculo, uma nova resistência... As três fases do jo-ha-kyu impregnam os átomos, as células, todo o organismo de uma performance japonesa. Elas se aplicam a cada uma das açóes do ator, a cada um de seus gestos, à respiração, à música, a cada cena teatral, a cada peça na composiçấo de um dia nô. É um tipo de código de vida que percorre todos os níveis de organizaçáo desse teatro. (Barba, 1982a, p. 22).

$\mathrm{Na}$ dança do cervo que eu vi em 1981, eu registrei as seguintes fases. (1) $\mathrm{O}$ interlúdio, ou esfriamento/aquecimento ocorreu tanto antes da dança quanto depois, formando um tipo de pano de fundo de ordinariedade do qual as características extraordinárias da dança emergiram. Durante o interlúdio todo mundo relaxou. Havia muita conversa, cigarros, café, perambulação. (2) Jovens Pascolas começam a dançar, sem máscaras, acompanhados de dois homens velhos tocando um violino e uma harpa. Pascolas são palhaços rituais yaqui. Eles frequentemente usam máscaras de animais ou demônios - mas nunca uma máscara de cervo. Pascolas interagem com os espectadores, fazendo troça deles (como fizeram de mim). Yaquis e acadêmicos concordam que os Pascolas são antigos, talvez mais velhos que a dança do cervo, mas 
a música Pascola é feita com instrumentos europeus. Os tambores d'água, raspadores, apitos e tambores de pele da dança do cervo são dos nativos americanos. Enquanto os jovens Pascolas dança, apenas uns poucos yaquis assistem (os acadêmicos eram arrebatados: observadores profissionais). Esta fase da dança era também um tipo de sessão pública de treinamento. Depois, quando a dança do cervo tinha acabado, dois dançarinos menos habilidosos dançaram em uma sessão de prática. Valencia confirmou que a prática acontece de fato desse modo, em ensaios públicos bem como em particulares. Pascola e cervo dançam das duas formas, juntos e alternadamente. A dança e a música mostraram as camadas de elementos nativos americanos e euroamericanos. Pascola é ao mesmo tempo mais velho é mais novo que o cervo. (3) À batida do tambor de pele e ao soprar do apito, o dançarino de cervo começa a colocar sua máscara. Os jovens Pascolas dançam com suas máscaras, mas o cervo não dança. Há uma mistura de música do violino, harpa, tambor de pele, e apito. (4) $\mathrm{O}$ tambor d'água e os raspadores começam a tocar música; o violino e a harpa param de tocar. (5) $\mathrm{O}$ cervo, mascarado, dança enquanto na outra ponta do galpão os velhos Pascolas, mascarados, dançam. Aqui há um tipo de confronto entre o "mundo floral" do cervo - ingenuamente natural - e algo mais parte-demoníaco-parte-humano representado pelos Pascolas. Durante esta fase os cantores cervos cantam, soam os tambores d'água e raspadores, o cervo sacode seu chocalho. Aqueles que desejam ver um drama mimético na dança do cervo sentem que esta fase inclui uma sugestão do cervo sendo caçado. (6) O Pascola mais velho, mais sênior, dança. O tempo é mais rápido. Esta é a "dança completa” e inclui o confronto direto entre o cervo e o Pascola conforme o Pascola se movimenta de sua ponta do galpáo para o território do cervo. Aqui, certamente, aqueles que procuram por ação mimética podem detectá-la. A música é produzida apenas pelos instrumentos do cervo: tambores d'água, raspadores, tambores de pele, apitos. O harpista está fumando nos fundos do galpão: o violinista permanece de pé e assiste com um distanciamento calculado. (7) O Pascola se retira para os fundos do galpáo. $\mathrm{O}$ cervo dança solo. Quando o Pascola sai, o tambor de pele e o apito param, mas a canção do cervo, os tambores d'água, e raspadores continuam. Esta parece ser a sessão mais velha, profunda, mais "essencialmente do cervo". (8) Tudo para. Esta parada acontece subitamente - apenas um final para a canção, e é isso. Há conversa no galpão. O cervo remove a máscara. Os dançarinos Pascola vagam. Violino e harpa começam a se afinar para outra rodada de oito fases. A fase $8=$ fase 1 .

$\mathrm{O}$ padrão de oito fases da dança do cervo se parece, conforme eu percebi, como o padrão jo-ha-kyu descrito por Zeami muitos séculos atrás. Não se trata aqui de difusão. $\mathrm{O}$ que temos aqui é minha aplicação de uma teoria japonesa de estética em um gênero nativo americano. Os Antropólogos podem se deter diante disso. Eles exigem que o observador participante "veja com o olho nativo" e talvez até mesmo "sinta com o coração nativo". Mas tem que se tomar muito cuidado com essas exigências para que elas não se tornem meramente uma arrogância açucarada. Quem pode determinar o que o olho nativo vê ou o coração nativo sente? Eu prefiro deixar que os "nativos" falem por si mesmos. De minha parte, eu assumo que estou vendo com meus próprios olhos. Eu também convido outros a ver a mim e a minha cultura com os seus. Nós estamos então em posição de trocar nossas visóes.

Usar estética interculturalmente se relaciona diretamente com a teoria social. Por exemplo, o "drama social" em quatro partes de Turner ruptura, crise, ação reparadora, reintegração (ou cisma) - é derivado do modelo greco-europeu de drama. Mas, como Turner disse, às vezes uma fase de um drama social fervilha por anos e anos, às vezes não há resolução mesmo depois de uma 
série climática de eventos. Grande excitação é seguida de uma interrupção súbita ou o cessar do tumulto: não é que tudo esteja resolvido como no final de Hamlet. Se Turner tivesse usado o modelo jo-ha-kyu, ele poderia ter visto a longa inflamação como jo, a súbita erupção da crise como ha, e a rápida ascensão rumo ao clímax como kyu. Então, ou a crise se resolve por meio da ação reparadora (como Turner a chama) ou ela retrocede para um outro longo jo. Este padrão não se encaixa em todos os dramas sociais, mas tampouco o faz o esquema greco-europeu de quatro fases do Turner. Pode haver dramas sociais melhor contemplados pelos termos da estética japonesa do que pelos da greco-europeia, pois alguns dramas sociais não se resolvem mas passam de um clímax, um kyu, para uma nova fase lenta, jo. Pode ser que o jo-ha-kyu, em algumas circunstâncias, seja um subconjunto da fase de ação reparadora de Turner.

Há uma variedade de teorias de performance "básicas" originando-se em diferentes culturas. Cada uma delas pode ser usada individualmente ou em combinação como uma lente através da qual pode-se focar tanto sistemas sociais quanto estéticos. Como Beverly Stoeltje da Universidade de Texas me disse quando discutimos estas ideias em abril de 1983, "Eu tenho esta imagem de um caleidoscópio de sistemas estéticos que pode se voltar para qualquer tipo de dados, produzindo diferentes perspectivas". Uma perspectiva verdadeiramente intercultural é de fato uma multiplicidade de perspectivas. De onde vem estas teorias de performance? É axiomático que a vida social precede a vida teatral? Esta é claramente uma ideia platônica- aristotélica: a arte imita a vida. Mas talvez a visão hindu-sânscrita tal como expressa no Natyasastra seja mais apropriada para estes tempos pós-modernos, reflexivos. O teatro e a vida ordinária são uma fita de Moebius, cada um tornando-se o outro.

\section{Interaçóes entre audiência e performer}

\author{
$\mathrm{Na}$ Institutional Church of God in Christ do
} Brooklin, em um domingo em fins de agosto de 1982, um grupo de antropólogos e acadêmicos visitantes foram recepcionados pelo pastor da igreja, o Bispo Carl E. Williams. Estes não-membros eram parte de um Simpósio Internacional de Ritual e Teatro ${ }^{2}$. O comparecimento à Institutional era parte de um programa de nove dias que incluía, somado às comunicaçóes e painéis usuais, uma variedade de performances, incluindo Squat Theatre ${ }^{3}$, um grupo experimental; A Chorus Line, o hit da Broadway; cerimônias conduzidas por xamãs coreanos; $\mathrm{Ku}$ tiyattam, um teatro sânscrito de Kerala, Índia; nô; e um grupo de música, dança e drama da Nigéria (moderno mas com muitos elementos tradicionais africanos). Obviamente, os participantes receberam mensagens performativas contrastantes.

Os xamãs coreanos e o pastor, diáconos, e a congregação da Institutional Church requisitaram, demandaram, precisaram que quase todos os presentes participassem. As pessoas se levantaram de seus assentos, movimentaram-se livremente no espaço, cantaram e dançaram nos espaços entre os bancos (na igreja) e em um grande círculo (com os xamãs). Era impactante quão semelhante eram a cerimônia coreana e o culto da igreja negra - ainda que, novamente, não fosse uma questão de difusão ou influência mútua. Em ambas as performances as pessoas alcançavam a alegria, até o êxtase, cantando e dançando. Em ambos os rituais um líder carismático (a xamã chefe, uma mulher esguia poderosa, Madame Kim, na casa dos cinquenta anos; bispo Williams, um enorme homem do tipo Deus-Pai com mãos poderosas) era o foco da cerimônia. A música forte tornava a dança uma necessidade: os tocadores coreanos de tambor, o coro negro da igreja, cantores gospel, e a congregação impelida por um piano, tambores, 
tamborins e um órgão. Madame Kim compartilhava comida com todos, tirava pessoas de seus assentos para dançar em círculos, performatizava um andar de lâmina de faca com os pés descalços. A congregação na Institutional participava com palmas e balançando os braços, gritando e dançando. Em ambas as cerimônias a coleta de dinheiro e sua exibição eram atributos chave. Todos sabiam do sucesso da cerimônia pela quantidade de dinheiro, a intensidade da participação, o grande número de pessoas dançando, cantando, batendo palmas, remexendo. Um ponto de virada na Institutional surge quando não apenas membros regulares da congregação, mas também antropólogos visitantes e pessoas do teatro se alinharam para receber as bênçãos das mãos do bispo Williams. Naquele momento a linha entre os participantes e os visitantes se dissolvia parcial e triunfantemente. A visitante que entrava profundamente em transe quando foi tocada era uma acadêmica coreana de xamanismo (residindo por alguns anos na América). De sua própria cultura ela sabia o que era esperado dela no Brooklin, ainda que estas duas culturas - coreana, afro-americana - não tivessem interagido previamente.

Nós precisamos saber mais sobre as interaçóes entre audiência e performer. $\mathrm{O}$ que acontece quando a performance viaja, sendo apresentada para audiências que nada sabem sobre os contextos sociais e religiosos do que elas estão experienciando? Certamente Madame Kim achou um pouco desconcertante xamanizar para pessoas que não falavam coreano ou precisavam de seus serviços. Por outro lado, eu me senti em casa na Institutional. Lá, membros da igreja nos convocaram para voltar, o que eu fiz. Os cristãos são proselitistas. Mas fez diferença o fato de que a audiência era quem tinha "viajado" - mesmo que fosse apenas até o Brooklyn. Sem dúvida audiências viajantes estão mudando performances em todo lugar. Isto é mais do que os resultados do turismo. Isto também é uma função de pessoas que são muito sérias sobre suas idas ao teatro. Ultimamente, audiências em Nova Deli, Nairóbi, ou Nova Iorque incluem pessoas que, cinquenta anos atrás, não "pertenceriam" a nenhum desses lugares. Audiências estão cada vez mais sofisticadas e cosmopolitas. Mudanças na audiência levam a mudanças na performance.

Michelle Anderson descreve as três formas de vodu que ela pesquisou recentemente no Haiti: uma forma ritual/social "apenas" para haitianos (embora ela estivesse lá), uma forma social/teatral para haitianos e turistas, e uma forma teatral/comercial "apenas" para turistas (embora alguns haitianos estudando estes diferentes tipos de eventos estivessem lá). Anderson diz que estas três formas tomadas em conjunto compunham o vodu "autêntico".

Nansoucri representa o vodu que teve a menor exposição a influências não-haitianas recentes. Mariani teve a maior exposição, e vividamente exemplificava adaptaçóes a essas influências... vodu em Jacmel era o mais revelador dos três: ele incorporava o processo de re-arranjo, do estágio de distorção, de liminaridade, pelo qual o vodu precisa continuamente passar - de um jeito ou de outro - em seu caminho, mas nunca alcançando, uma forma apropriadamente responsiva ou "acabada". O ritual vivo, como o teatro vivo, nunca está acabado. (1982, p. 99).

O que faz estas mudanças - que mantém o vodu "vivo" - é a audiência que se modifica. E é o que pode matá-lo também, pois há um limite de mudança que um gênero pode absorver até deixar de ser ele mesmo.

\section{A sequência total da performance}

De modo geral, acadêmicos prestaram atenção ao show, não à sequência total de sete partes, de treinamento, oficinas, ensaios, aquecimentos, 
performance, esfriamentos e balanço. Pessoas do teatro investigaram treinamento, ensaios, e performances mas deixaram passar as oficinas, aquecimentos, resfriamentos, e balanços. Assim como as fases da performance pública em si fazem um sistema, toda a "sequência de performance" faz um sistema maior, mais inclusivo. Em alguns gêneros e culturas, uma ou outra parte da sequência é enfatizada.

No drama nô, por exemplo, o extenso treinamento do shite tradicionalmente começa quando ele tem cinco anos de idade. Este treinamento, desde o começo, consiste em aprender partes das performances nô. Alguns aspectos das performances - o modo como os pés se movem, o encaixe da coluna, o estilo da entoação - são constantes de papel para papel. Ao aprender as especificidades desse ou daquele papel, o neófito também aprende os princípios básicos do nô. Aos poucos, o aprendiz acumula informação concreta suficiente para performar papéis simples.

Em seu Kyui, Zeami delineia nove níveis de atuação, divididos em três grupos (ver também capítulo 5). Zeami aconselha o jovem ator a começar com os três níveis do meio. "A marca do projeto da superfície [naturalismo, imitação pura] é considerada a primeira entrada no caminho do estudo dos nove níveis" (Zeami, in Nearman, 1978, p. 314). Depois que o performer domina os níveis médios ele sobe aos três níveis mais altos. Apenas depois de aprendê-los ele desce aos três primeiros níveis, os mais primitivos e toscos. Estes papéis, diz Zeami, requerem uma perícia que apenas um mestre shite pode oferecer: a habilidade de equilibrar o grotesco de um papel com a sutileza de como ele é performatizado. Apenas depois de um shite dominar a sublimidade dos três níveis mais altos ele está equipado para descer aos níveis mais baixos. Este é ainda um outro aspecto da transformação incompleta: em papéis dos níveis mais baixos a máscara é tosca enquanto o rosto parcialmente revelado é sublime. Zeami nota, com tristeza, que "mesmo hoje [o século XV] na nossa arte, há colegas que tratam os três níveis mais baixos como a primeira entrada para o estudo do Caminho e performam de acordo. Esta não é a rota certa” (1978, p. 330).

Os segredos do treinamento de Zeami foram mantidos na família Kanze - passados por gerações em grande parte por transmissão oral - até este século. Estes ensinamentos formam o núcleo do estilo de performance Kanze. Tal ênfase em um treinamento detalhado fez com que ensaios e oficinas no sentido euroamericano se tornassem desnecessários no teatro nô. Em uma performance tradicional nô - com uma adesão ampla ainda hoje - os shite invocam os outros grupos de performers, todos os quais praticaram separadamente - os tocadores de tambor, flautistas, waki (papel secundário, sem máscara), e kyogen (interlúdio) - e explica a eles o que ele pretende com esta performance. Ele pode indicar ou mesmo demonstrar alguns mai (movimento de dança) se ele planeja algo incomum. Mas o único momento em que o nô como um todo será realizado é durante a performance em si. O shite e o coro compóem uma unidade performática, o waki outra, os tocadores de tambor outra, e assim por diante. Que estes grupos radicalmente separados de especialistas podem, durante a performance propriamente dita, trabalhar juntos como um conjunto esplêndido mostra às pessoas do teatro ocidental que há mais de um jeito de dar conta do recado.

Às vezes, no teatro clássico indiano, preparações antes de uma performance são muito importantes. Isto parece ter sido verdade na Índia desde o começo. O Natyasastra dedica o capítulo 5 "as preliminares de uma peça". Estas incluem tocar tambores e instrumentos de corda como um modo de contar ao público que a performance vai começar; conduzir diversos rituais honrando os deuses; fazendo vários tipos de danças introdutórias e circunvoluções no palco. Hoje, se todas essas preliminares fossem performatiza- 
das, elas levariam várias horas; normalmente elas são muito abreviadas. Antes das preliminares no palco, há aquelas no salão verde. Em Kutiyattam (a forma mais antiga sobrevivente na Índia, datando pelo menos do século X) vestir a fantasia e aplicar a maquiagem ornamental no corpo e no rosto leva pelo menos duas horas; e o mesmo para Kathakali. Cada dia antes do Ramlila, os garotos que fazem os papéis principais ensaiam por duas horas e gastam mais duas entrando em fantasias e maquiagem. Mas os homens que interpretam os mesmos papéis todo ano dificilmente sequer ensaiam. Por contraste, Actors' Equity, o sindicato dos atores americanos, tem uma regra exigindo que os atores estejam no teatro meia hora antes da cortina. Alguns atores chegam antes, mas muitos não. Músicos de jazz afinam os seus instrumentos no palco com a audiência presente. Squat Theatre não ensaia, treina ou se aquece. Os membros discutem os procedimentos exatos da performance, constroem seu ambiente físico, e esperam pela performance de fato para fazer o que planejaram. Este método, eles dizem, gera frescor à performance de cada noite (ver Schechner, 1978).

Discutir o esfriamento das performances é mais difícil porque a documentação é escassa. $\mathrm{O}$ esfriamento deve ser investigado do ponto de vista tanto dos performers quanto dos espectadores. Os espectadores, tendo experimentado a performance, foram afetados por ela. Depois do Ramlila de Ramnagar os garotos que interpretam Rama, Sita, e os irmãos de Rama são carregados de volta ao lugar onde vivem durante o mês das performances. Exceto quando estão performatizando não se permite que seus pés toquem o chão enquanto eles estáo vestindo toda a ornamentação. Uma vez que suas fantasias são removidas, eles comem uma rica refeição especial com leite integral, iogurte, frutas, nozes, e doces. Logo eles adormecem. Performers mais comuns tiram suas fantasias, comem, e socializam; alguns recitam oraçóes ou vão a um templo para o puja. Não há comportamento prescrito para todos seguirem. A audiência também se separa em diversos grupos. Muitos vão direto para casa pelos meios mais eficientes. Eu não sei o que fazem. Alguns alugaram quartos em Ramnagar por todo o mês do Ramlila. Estes nemis - espectadores cheios de fé e devoção - podem ler o Ramcharitmanas, cantar cançóes devocionais, ou de outros modos continuam seu culto a Rama. Um grupo de pessoas se reúne diante de pequenos santuários na estrada de volta ao centro de Ramnagar e entoam kirtans com sadhus cujo canto preenche a noite. Muitos espectadores embarcam em barcos a remo para a viagem de trinta minutos pelo Ganga para voltar a Varanasi. Enquanto estão no rio sagrado eles cantam cançôes sobre Rama, Sita, e Hanuman. Estas atividades mantém o lila do dia firme no coração e na mente.

Em Bali, é tão importante tirar um dançarino do transe quanto fazê-lo entrar. Fumaça é inalada, água benta aspergida, e às vezes uma galinha é sacrificada. Na Institutional e em outras igrejas indutoras de transe, negras ou brancas, quando um irmão ou irmá "cai” (em transe) um grupo de amigos e parentes se junta ao redor, previne a pessoa em transe de cair ou de algum modo machucar a si mesmo ou aos outros, e a acompanha de volta ao assento. Lá, frequentemente, a pessoa em transe é abanada, tem sua fronte enxugada: o calor do êxtase religioso é reduzido. Eu fiz experimentos com exercícios de esfriamento - respiração em grupo, a passagem de água, algumas conversas baixas sobre a performance (nada crítico, apenas como uma forma de trocar experiências).

Em teatros por todo o mundo, depois de um show os performers comem, bebem, conversam e celebram. Um novato entre os atores se pergunta como tanta energia sobra para estas rodadas depois-do-teatro. Mas a verdade é que estas atividades não ocorrem "depois" mas "são parte" da performance e deveriam ser estudadas como 
tal. Em muitas culturas, ingerir alimentos e bebida, compartilhar memórias do que aconteceu, é ou a conclusão da performance ou parte de cerimônias depois-da-performance. Parece que uma performance realizada de todo o coração literalmente "esvazia" os performers, e um modo de eles se restabelecerem (ou ser restabelecidos) à vida ordinária acontece quando são reabastecidos com comida e bebida, sagrada e profana. $\mathrm{Ou}$, ao contrário, a performance preenche tanto os performers com energia e excitação que eles precisam de tempo para extravasar através de uma socialidade exuberante.

O balanço é ainda menos sistematicamente discutido que o resfriamento. $\mathrm{O}$ balanço diz respeito às consequências a longo prazo ou o seguimento dado a uma performance. $\mathrm{O}$ balanço inclui as mudanças de status ou do ser que resultam de uma performance iniciática; ou a lenta fusão de um performer com o papel que ele interpreta há décadas (ver capítulo 3) ${ }^{4}$; ou as resenhas e críticas que tanto influenciam algumas performances e performers; ou teorizaçóes e produções acadêmicas - como este livro. Dada a distância das resenhas, críticas, teorias, e carreiras acadêmicas são construídas não nas artes ou rituais performáticos, mas ao comentar as performances. Claro, os balanços se alimentam de performance - e teorias dos praticantes como Brecht, Stanislavski, e Zeami são exemplos especialmente instrumentais.

Ao limitar suas investigaçóes a principalmente o que acontece durante a performance propriamente dita, acadêmicos estão seguindo a convenção teatral moderna euroamericana: você não vai para os bastidores a menos que seja parte do show. A história do desenvolvimento da casa de espetáculos ocidental tem sido a substituição de um evento que era em grande parte aberto, público e a céu aberto; por um evento fechado, privado e em lugar fechado.

Como eu observei antes, as sete fases da performance - treinamento, oficinas, ensaios, aque- cimentos ou preparaçóes imediatamente antes da performance, a performance propriamente dita, esfriamento, e balanço - não são igualmente enfatizadas em todas as culturas. Performances tradicionais - a missa, peças de Purim, nô, e assim por diante - normalmente exigem treinamento mas muito pouco ensaio. É óbvio: se você interpreta o mesmo papel muitas vezes, como na Ramlila, ou se há uma progressão ordenada, prevista de papéis que estão diante de você por anos, como no drama nô, a ideia de definir o que fazer de antemão é desnecessária - duplamente desnecessária se o mise-en-scène é fixado pela tradição. Mas em culturas, como a euroamericana, na qual a "originalidade" é valorizada (tão valorizada que os trabalhos são louvados simplesmente por serem "novos"), ensaios são frequentemente mais importantes que treinamento. A maiorias dos atores americanos esperam ansiosamente o momento em que eles "terminaram" o treinamento. Da boca para fora, valorizam os treinamentos por toda a vida, mas de fato apenas uma pequena fração de atores continua o treinamento depois de deixar a escola de atuação. Os dançarinos mais frequentemente continuam seu treinamento provavelmente porque um dançarino sem um corpo flexível é descartado. Mas quantos dançarinos se "dedicam mesmo" a seu treinamento. Se uma dançarina pudesse manter sua forma física sem treinar, ela treinaria mesmo assim? Por outro lado, a maioria dos performers gosta de ensaios. É neles que o "trabalho criativo" é feito. Caracterizaçôes são construídas, coreografia inventada ou aprendida, os muitos elementos que compóem uma performance são testados. Quão diferente é tudo isso em relação ao nô. No teatro euroamericano não é tão importante que um artista seja modelado a se conformar a um conjunto particular de expectativas performáticas já dispostas pela tradição. É mais importante que o "instrumento" do artista (= corpo e alma) esteja apto a se adaptar flexivelmente para este 
ou aquele grupo temporário de pessoas e com elas suave e eficientemente liberar sentimentos e, junto com o coreógrafo ou diretor, inventar ou invocar um estoque de movimentos, gestos, vozes, e emoções. Se isto é realizado com sucesso, talvez as audiências acreditem que este grupo temporário é um "conjunto".

Desde por volta de 1960, e especialmente no teatro e na dança experimentais, uma situação emergiu na qual tanto o roteiro quanto o mise-en-scène são "pesquisados" e compostos em uma fase performativa especial, entre o treinamento e os ensaios, chamada de oficina. No teatro que surge da oficina, não há roteiro pré-existente - ou há roteiros demais ('materiais" ou "fontes"). As palavras não determinam tudo o mais, mas são costuradas em um texto performático que consiste em muitos fios trançados: iluminação, fantasias, cenografia, iconografia (os arranjos dos performers no espaço), arquitetura teatral, música e assim por diante. Há também muitas oficinas que não levam a performances públicas. Habilidades tão diversas quanto t'ai chi ou confecção de máscaras são aprendidas. $\mathrm{Ou}$, como no trabalho "parateatral" de Grotowski e outros, uma intensa experiência pessoal acontece. Este tipo de trabalho beira o "movimento potencial humano", um movimento que tirou muitas de suas técnicas do teatro, dança e música.

Observando a sequência total de performance de sete fases, eu encontro um padrão análogo aos ritos iniciáticos. A performance envolve uma separação, uma transição, e uma incorporação (Van Gennep [1908] 1960). Cada uma dessas fases é cuidadosamente marcada. Nas iniciações as pessoas são transformadas permanentemente, enquanto que na maior parte das performances as transformações são temporárias (transportaçôes). Como nas iniciações, as performances "fazem" uma pessoa tornar-se outra. Diferentemente das iniciações, as performances normalmente cuidam para que o performer recupere seu eu. Para usar as categorias de Van Gennep, treinamento, oficina, ensaio e aquecimentos são preliminares, os ritos de separação. A performance propriamente dita é liminar, análoga aos ritos de transição. Esfriamento e balanço são pós-liminares, ritos de incorporação. Estas fases do processo ritual também podem se aplicar de um outro modo à performance.

Quando as oficinas e ensaios são usados juntos, eles constituem um modelo para o processo ritual (ver também os capítulos 2 e 6$)^{5}$. Oficinas, que desconstroem a experiência ordinária, são como ritos de separação e transição enquanto ensaios, que erguem, ou constroem, novos itens culturais, são como ritos de transição ou incorporação. Oficinas ou ensaios convergem em um processo de transição. Uma das vantagens para os teóricos da performance do talmud de Turner sobre Van Gennep é a flexibilidade extremamente sugestiva do processo ritual tal como Turner o interpreta.

\section{A transmissáo do conhecimento performático}

O que é "conhecimento performático"? Por muito tempo, no teatro pelo menos, o conhecimento performático foi identificado com conhecer os grandes textos dramáticos (de Ésquilo, passando por Shakespeare, para Ibsen, Chekhov, Pirandello, e Brecht até Beckett). O que os performers e diretores fizeram era conhecido mas segregado. Então, nos anos sessenta, vem um tempo de ascendência do prático - na América formaram-se numerosas "escolas conservatório" de teatro. Os estudantes aprenderam os ofícios do palco mas pouca literatura e menos ainda teoria. Mas o conhecimento performático é integrativo.

Patrice Pavis em seu Languages of the Stage identifica seis tipos de textos usados no teatro: 
1. Texto dramático: o texto composto pelo autor que o diretor é responsável em encenar...

2. Texto teatral: o texto em uma situação concreta de enunciação em uma área concreta diante de uma audiência.

3. Performance: a reunião dos sistemas de palco usados, incluindo o texto, considerado anterior ao exame da produção de significado por meio de suas interrelaçóes.

4. Mise-en-scène: a interrelação dos sistemas de performance, particularmente... a ligação entre o texto e a performance.

5. Evento do teatro: a totalidade da produção desdobrada do mise-en-scène e sua recepção pelo público, e as trocas entre elas.

6. Texto performático: o mise-en-scène de uma leitura e qualquer avaliação possível feita dessa leitura pelo espectador (1982, p. 160).

Este tipo de separaçáo dos diferentes tipos de códigos de performance é necessário se nós queremos compreender a performance interculturalmente e teoricamente. Eu não concordo inteiramente com as distinçóes de Pavis - eu uso "texto performático" para significar o que acontece durante uma performance tanto no palco quanto fora dele, incluindo a participação $\mathrm{da}$ audiência. Normalmente o que acontece no palco pode ser transmitido por um mestre a um neófito, e estas açóes constituem a maior parte do que é ensinado durante o treinamento. $\mathrm{Eu}$ concordo enfaticamente com Pavis sobre a necessidade de se desenvolver uma terminologia descritiva detalhada.

Isto é assim porque agora já é muito claro que uma performance é muito mais complexa do que a "encenação de um roteiro". Tanto historicamente em termos das origens da performance quanto interculturalmente em termos das performances que acontecem agora, a encenação de textos escritos compreendem uma pequena fração da atividade do teatro mundial. Falando sobre o que pode ter sido o teatro mais antigo do mundo, os eventos ocorridos nas cavernas paleolíticas no sudoeste europeu, eu escrevi em 1973:

Nós nada sabemos dos "roteiros" usados pelos dançarinos-xamãs dos templos-teatros paleolíticos... Eu digo "roteiros", significando algo que preexiste a qualquer encenação, que funciona como um plano para a encenação, e que persiste de encenação para encenação. Extrapolando as evidências existentes e experiência moderna, eu presumo que dançar [nas cavernas] tomou uma forma persistente (ou "tradicional") que foi mantida de uma instância para outra; que esta forma foi conhecida pelos dançarinos e pelos espectadores [se é que houve algum], e que esta forma era ensinada por um grupo de dançarinos para outro. O mais provável é que este ensino não fosse formal, mas por meio de imitação. Contudo, pode-se argumentar que a inacessibilidade das cavernas indicam um culto esotérico, e o que os "segredos" do culto poderiam ser definitivamente e formalmente transmitidos [...]

Contudo, a performance é meramente implícita ou potencial no roteiro; apenas muito mais tarde que o poder foi [...] absorvido pela palavra escrita. Para conceber essas performances muito antigas - algumas datando de 25 mil anos atrás - deve-se imaginar culturas absolutamente não-letradas; iletradas provavelmente é uma palavra melhor. Desenhos e esculturas, que no mundo moderno são associados com "signos" e "símbolos" (semelhança-com-palavras), nos tempos paleolíticos são associados com feitos (semelhança-com-teatro). Assim, os "roteiros" dos quais eu estou falando são padrôes de fazer, não modos de simbolização separados do fazer. Mesmo falar não é fundamentalmente configurado (palavras-como-escritas) mas sonorizado (palavras-como-respiração e tom vocal). Em última análise, muito depois que a escrita foi inventada, o drama surgiu como uma forma especializada de inscrição. A manifestação potencial que foi previamente codificada em um 
padrão de fazer foi entáo codificada em um padrão de palavras escritas. Os dramas dos gregos, como Aristóteles indica, continuam a ser códigos para a transmissão de ação, mas ação não significa mais um modo específico, concreto de mover-se/ cantar - foi entendida "abstratamente" ou metaforicamente, como um movimento nas vidas das pessoas. Falando historicamente, no ocidente, o drama se desprendeu do fazer; comunicação substituiu manifestação (1973a, p. 6-7).

Assim a literatura dramática surgiu em lugares específicos e em circunstâncias históricas específicas. $\mathrm{O}$ teatro não literário, não-escrito continua a vicejar. Às vezes, como no nô e Kathakali, uma extensa literatura teatral existe, mas é aprendida como parte de seu uso de fato na performance.

O conhecimento performático pertence a tradições orais. Como tais tradições são transmitidas em diferentes culturas e em gêneros diferentes é de grande importância. Alguns paralelos surpreendentes existem, por exemplo, entre o modo como os esportes profissionais na América e performances tradicionais na Ásia são treinados e ensinados. Esportes são bons exemplos de performance não-verbal - dramático e cinestésicos, e ainda assim não são "danças" ou "teatro" no sentido clássico, moderno ou pós-moderno. Os treinadores dos times esportivos são normalmente antigos jogadores. Eles passam seus "segredos" pessoalmente aos jogadores mais novos. Jogadores mais velhos, mesmo quando não podem mais jogar, são respeitados por seus recordes; os participantes e fầs se divertem com anedotas sobre os antigos "grandes" esportistas. Alguns destes ancestrais são consagrados no "hall da fama", e alguns são mantidos como treinadores ou executivos. Isto não é muito diferente do que acontece com muitos performers respeitados de Ramlila, nô, Kathakali, dança coreana, e assim por diante pela Ásia afora. Antigos performers ensinam, alguns são designados “tesouros nacionais vivos”, e papéis são reservados para que eles os interpretem.

Em outro lugar, eu discuti o problema da transmissão do conhecimento performático tal como ocorre na vanguarda americana (ver Schechner, 1982b). Quando as pessoas do teatro souberem mais como rituais e performances tradicionais são transmitidas o problema será menos intratável. Algum progresso foi feito. Centenas de trabalhadores da dança e teatro ocidentais estudaram técnicas performáticas asiáticas e africanas. Tenho conhecimento sobretudo daqueles que foram na Índia, no Japão e na Indonésia. O que é importante sobre esses contatos não é a apropriação direta de modos asiáticos - estas imitaçóes podem ser embaraçosas - mas a adaptação a circunstâncias americanas de padróes subjacentes, o próprio pensamento da performance: a relação mestre-aprendiz; a manipulação direta do corpo como um meio de transmitir conhecimento performático; respeito pelo "aprendizado do corpo" como distinto do "aprendizado da cabeça”; também, a consideração do texto performático como uma trança de várias "linguagens" performáticas, sem que nenhuma possa exigir a primazia. ('Linguagens" está entre aspas porque eu desconfio do modelo linguístico aplicado à performance. Eu creio que Aristóteles estava mais perto da razão quando ele identificou "ação" [praxis] como o núcleo da performance: um sistema muito denso e dinâmico de alternar valências e torcer hélices. Se os teóricos da performance precisam de uma metáfora guia, nós provavelmente as encontraremos na física das partículas ou na biologia do que na linguística).

Claro que as vias Ocidente-Oriente/Sul-Norte estão repletas de tráfego em ambas as direçóes. Centenas de africanos, asiáticos, e latino-americanos têm vindo à Europa e América para estudar performance. No começo estas pessoas trabalharam principalmente nas principais correntes euroamericanas, e levaram 
de volta para suas culturas versóes do teatro, da dança e da música ocidentais modernas. Porém, mais recentemente, muitos não-ocidentais participaram de performances experimentais. Isso levou ao desenvolvimento de companhias interculturais e uma troca maravilhosamente complicada de técnicas e conceitos que não podem mais ser facilmente situadas como pertencendo a esta ou aquela cultura. Este diálogo relacionando elementos modernos, tradicionais e pós-modernos acontece mesmo no interior de uma nação. Uma conferência realizada em Calcutá em 1983 se focou na relação entre os gêneros de dança-drama clássicos indianos e o teatro moderno. Atores, dançarinos, músicos, e acadêmicos de todo o mundo se reuniram. $\mathrm{O}$ diretor de teatro Mohan Agashe, de Pune, Índia, salientou que a relação entre os gêneros e culturas dentro da própria Índia não podem simplesmente ser o de tomar este passo de dança, aquele ritmo, ou aquela história mas precisa ser mais como o metabolismo no qual o aprendizado profundo tem lugar, do que decorrem trabalhos artísticos que não se parecem em nada com aqueles dos quais surgiram. O teatro euroamericano é cheio de exemplos do processo metabólico de que fala Agashe. Os marionetes do Shaggy Dog Animation de Mabou Mine combinam o bunraku japonês com as marionetes de vaudeville euroamericanas, tal como tipificadas pelo Charlie McCarthy de Edgar Bergen. As máscaras do Night Shadows de Islene Pindar foram confeccionadas por artistas balineses para sua Balinese-American Dance Company. Estas máscaras refletem as interpretaçōes balinesas das ideias de uma coreógrafa americana - uma americana que estudou em Bali. O Little Red Riding Shaw de John Emigh usam movimentos e máscaras topeng balinesas para contar uma história com uma veia muito americana. $\mathrm{Na}$ produção de Emigh do Círculo de Giz Caucasiano de Brecht, a dramaturgia básica (assim como as máscaras) refletem seu trabalho em Bali. Ron Jankins es- tudou clowning no Barnum and Bailey Clown College e em Bali, onde ele performatizou com uma trupe balinesa. Em seu One Horse Show Jenkins integrou suas experiências de tal modo que a superfície parecia muito americana mas os padrōes subjacentes combinavam culturas. As máscaras de Julie Taymor, não apenas para seus próprios shows mas também para o $\mathrm{Ha}$ ggadah de Liz Swados, são metabolizadas de modo similar das experiências de Taymor em Java. Philip Zarrilli ensina a arte marcial indiana do kalarippayatt como um treinamento básico do performer. Há um bom modelo para isso: muitos anos atrás muito do kalarippayatt foi levado para o regime de treinamento do Kathakali. Zarrilli também usa o kalarippayatt em suas próprias produçóes. Quando ele e eu colaboramos em Richard's Lear em 1982, o kalaruppayatt foi não apenas uma parte essencial do treinamento mas também da encenação de duas cenas de luta. A lista continua. Alguns trabalhos são também melhor metabolizados do que outros. Meu ponto é que estes novos tipos de performance trazem à existência novos meios de treinamento, significando novos modos e maneiras de transmitir conhecimento performático - novos para o Ocidente mas náo para a Ásia ou África.

As técnicas de transmissão de conhecimento performático são uma base forte para troca entre as pessoas do teatro e os antropólogos. As pessoas do teatro entendem de treinamento: é esperado que os professores de teatro sejam capazes também de praticá-lo, o que significa que os professores foram treinados como atores, diretores, cenógrafos, figurinistas, etc. Os antropólogos são observadores treinados; e alguns antropólogos - não o suficiente, mas em um número crescente - também participam das culturas que eles observam. As pessoas do teatro podem ajudar os antropólogos a identificar o que procurar em um treinamento ou situaçáo de performance; e antropólogos podem ajudar 
as pessoas do teatro a ver performances dentro do contexto de sistemas culturais específicos.

\section{Como as performances são geradas e avaliadas?}

As avaliaçóes variam de consideraçóes totalmente subjetivas como "eu gostei disso" às análises semióticas detalhadas; de um professor indicando o que foi útil mesmo em uma performance fracassada até a resposta entusiasmada de um espectador sofisticado - ou a resposta confusa de um espectador ignorante. Nas performances asiáticas a avaliação da performance é parte da própria performance. Antes dos dias dos críticos de jornais havia os patronos. Uma performance nô ou Kathakali é considerada tão boa quanto aqueles que a assistem "mereçam". Uma pessoa que patrocina ou ainda assiste um drama nô supostamente tem um conhecimento considerável sobre ele. Um connoisseur sabe o que se oferece a ele e pode reagir apropriadamente. A comparaçáo com a atitude americana sobre esportes é novamente instrutiva. Espectadores de esportes sabem as regras do jogo, e os melhores lances da partida. Eles conhecem os jogadores e seus recordes: eles sabem a história de cada time: eles debatem as decisóes de gestão desde estratégias em campo até finanças. Em resumo, cada aspecto do jogo, das partidas, e dos jogadores é debatido no calor da opinião informada. A excelência é aplaudida, jogos ruins vaiados. Os espectadores de esportes são connoisseurs. Se o teatro conseguisse atrair tal audiência, as coisas se tornariam rapidamente melhores.

Como uma performance "boa" pode ser distinguida de uma "ruim"? Há dois conjuntos de critérios, um para dentro da cultura e outro para a de fora? Ou há quatro conjuntos: de dentro da cultura por profissionais que também fazem performances; de dentro por audiências comuns; de fora da cultura por profissionais visitantes; de fora por audiências comuns? Quem tem o "direito" de fazer avaliações: apenas as pessoas dentro de uma cultura, apenas profissionais que praticam a arte em questáo, apenas críticos profissionais? Há uma diferença entre crítica e interpretação? (Clifford Geertz estudou, interpretou, criticou, ou resenhou a briga de galos balinesa?). A maioria dos artistas escarnecem dos críticos mas aceitam seus elogios. Estes mesmos profissionais apreciam a crítica de seus colegas performers oferecidas em privado. Ressente-se da natureza pública das opiniōes críticas e do poder dessas opiniōes em promover ou extinguir carreiras. Para quem é a avaliação: para os que fazem, os que assistem, os que poderiam vir a assistir? As resenhas de jornais são principalmente guias para o público. Periódicos acadêmicos variam enormemente em qualidade, e são publicados meses após a realização da performance. A falta de discussão imediata, crítica, mas não orientada ao consumidor prejudica gravemente as artes performáticas.

A única crítica realmente efetiva é aquela apoiada por mais prática. Durante cada noite de performance de qualquer coisa que eu dirija, eu tomo notas que entáo são compartilhadas no dia seguinte com os performers. As notas sempre demandam ensaios, o que é um processo contínuo. Vagarosamente, ao longo de meses ou mesmo de anos, algumas produçóes alcançam uma excelência por meio de um processo de fazer, ver, avaliar, criticar e refazer.

\section{Conclusóes}

Estes seis pontos de contato precisam ser alargados e aprofundados. Métodos antropológicos e teatrais estão convergindo. Um número crescente de pessoas em ambas as disciplinas está cruzando fronteiras. Grotowski, Brook, Barba, Turner, Turnbull, e outros estão trabalhando especifica e concretamente em modos que são interculturais e interdisciplinares. 
Desde 1970, Brook dirigiu seu International Center for Theater Research em Paris. Sua companhia inclui performers da África, Ásia, Europa e das Américas. Suas viagens de campo o levaram junto com seu grupo para todos estes continentes trocando técnicas e material de pesquisa com uma variedade de produções estendendo-se de The Ik (baseadas no Mountain People de Colin Turnbull), L'Os (baseadas em um conto africado de Birago Diop), e The Conference of the Birds (baseada em uma história sufi) até a versão ainda não-acabada do Mahabharata.

Por três meses em 1972-73 a trupe de Brook viajou para aldeias na Argélia, Niger, Nigéria, Daomé, e Mali. O que eles fizeram era bastante simples. Eles entraram em uma aldeia, desenrolaram seu "tapete de performance" - algo para definir o lugar no qual eles performatizariam - e expunham algumas improvisações. Após as improvisações, o grupo de Brook conversavam com os aldeães. A performance era "influenciada, segundo-a-segundo, pela presença das pessoas, o lugar, a hora do dia, a luz - todas essas coisas refletidas neles nas melhores performances" (1973, p. 41). Brook descreve o método de trabalho de seu grupo e a ideia central da viagem da seguinte forma:

Poder-se-ia chegar a uma aldeia na qual uma coisa como essa jamais ocorrera. Nós encontraríamos o chefe da aldeia e, por meio de um intérprete, talvez apenas uma criança da aldeia, eu conversaria com o chefe e explicaria em algumas poucas palavras o fato de que um grupo de pessoas, de diferentes partes do mundo, se lançaram a descobrir se um contato humano pode ser feito por meio dessa forma particular chamada teatro... Era um evento que sempre foi bem recepcionado, e sempre recebido em seus próprios termos por aquilo que era (1973, p. 43).

Mas estas eram trocas de fato? Ou a viagem era mais uma chance para o grupo de Brook ex- plorar técnicas de atuação improvisada enquanto fruía da hospitalidade local?

Uma vez sentamos em Agades [Niger] em uma pequena cabana por toda a tarde, cantando. Nós e o grupo africano cantamos, e subitamente descobrimos que estávamos atingindo exatamente a mesma linguagem do som. Bom, nós entendemos a sua e eles entenderam a nossa, e algo muito eletrizante aconteceu porque, dentre todos os tipos de cançóes diferentes, uma surgiu subitamente dessa área comum (1973, p. 45).

Em outra vez o grupo de Brook acampara numa floresta. Crianças apareceram e disseram a eles que em uma aldeia próxima tinha uma celebração acontecendo. Os atores foram.

Nós fomos muito bem vindos e sentamos lá, em completa escuridão, sob as árvores, apenas assistindo as sombras moventes dançando e cantando. E depois de um par de horas elas subitamente nos disseram: os garotos disseram que é isto que vocês fazem também. Agora vocês devem cantar para nós. Então tivemos que improvisar uma canção para eles. E este foi talvez um dos melhores trabalhos da jornada (1973, p. 45).

Não é sempre tão idílico, Brook - e outros realizando trabalhos similares - foram acusados de agir de modo arrogante, até imperialista.

Mas tendo dito isso, eu ainda simpatizo com o impulso fundamental de Brook (algumas vezes realizado de modo imperfeito), que é também o impulso de Jerzy Grotowski, Eugenio Barba, e Victor e Edith Turner, assim como outros, tanto euroamericanos quanto não-ocidentais:

Nosso trabalho é baseado no fato de que alguns dos aspectos mais profundos da experiência humana podem revelar-se por meio de sons e movimentos do corpo humano de um modo que atinge uma corda idêntica em qualquer observa- 
dor, seja qual for seu condicionamento... cultural. (Brook, 1973, p. 50)

Conforme Brook observa, "o corpo como tal se torna uma fonte de trabalho". Seja baseado na neurobiologia ou em manifestaçóes universalmente reconhecíveis de emoçóes, os aspectos afetivos do teatro tem menos necessidade de tradução que a literatura.

Barba, fundador-diretor do Odin Teatret na Dinamarca e um homem associado há muito tempo a Grotowski, no momento está desenvolvendo sua International School of Theatre Anthropology ISTA; ver capítulo 5). O ISTA envolve treinamento, trocas de técnicas, seminários, filmes, e um "time de colaboradores científicos". Duas sessóes da escola se encontraram por muitos meses cada uma entre 1980 e 1981, e mais foram planejadas. Além dos estudantes participantes e membros do Odin, totalizando cerca de 60 pessoas, professores vieram da Índia, Bali, Japão, Suécia, Dinamarca, e China. Barba descreve o ISTA e seus objetivos da seguinte forma:

Antropologia teatral é o estudo do comportamento biológico e cultural do homem em uma situaçáo teatral, ou seja, do homem apresentando e usando sua presença física e mental de acordo com leis que diferem daquelas da vida cotidiana. Existem leis que governam o uso particular do corpo do ator, i.e., sua técnica. Certos fatores biológicos (peso, equilíbrio, deslocamento de peso/ desequilibrar-se, a oposição entre peso e coluna vertebral, o modo de usar os olhos) tornam possível que se atinja tensôes orgânicas "pré-expressivas”. Estas tensóes determinam uma mudança na qualidade de nossas energias, fazendo com que o nosso corpo "torne-se vivo", de modo que atraia a atenção dos observadores muito antes da intervenção de qualquer expressão pessoal (1981, p. 2). Atores diferentes, em lugares e tempos diferentes, a despeito das formas estilísticas específicas de suas tradiçôes, utilizaram alguns princípios que eles tem em comum com atores de outras tradições. Traçar estes "princípios recorrentes" é a primeira tarefa da antropologia teatral. Os "princípios recorrentes" não são prova de uma "ciência do teatro" ou de algumas leis universais. Elas são "dicas", "informaçóes" particularmente bons que parecem ser muito úteis à prática teatral... Estas "dicas e conselhos" são particulares desse modo: podem ser seguidas ou ignoradas. Elas não são leis invioláveis. Antes - e este é provavelmente o melhor modo de usá-las - respeita-se-as para se poder quebrá-las e superá-las (1982a, p. 5).

Barba, de seu próprio modo, está estendendo o trabalho de Grotowski em desenvolver o treinamento do ator e mise-en-scène.

Turner fez pela antropologia o que Barba está fazendo pelo teatro. O trabalho de Turner se desenvolve por várias décadas e cobre grandes áreas conceituais. Desde os anos 60 ele estava interessado em ritual-como-performance e mais recentemente no que ele chamou de "etnografia performatizada”. Colaborando com sua esposa, Edith, Turner esteve,

experimentando a performance da etnografia para auxiliar a compreensão dos estudantes de como as pessoas em outras culturas experimentam a riqueza de sua existência social, quais as pressóes morais sobre eles, que tipos de prazeres eles esperam receber como recompensa por seguir certos padrôes de ação, e como eles expressam alegria, luto, deferência, e afeição, de acordo com expectativas culturais. $\mathrm{Na}$ Universidade de Virginia, com estudantes de antropologia, e na Universidade de Nova Iorque, com estudantes de teatro, nós tomamos descriçóes de faixas de comportamento de "outras culturas" e pedimos aos alunos para fazer "roteiros de cena" com eles. Entáo nós fizemos estas oficinas (workshops) - "oficenas" [playshops] - nas quais os estudantes tentam obter uma compreensão cinética de "outros" grupos socioculturais. Frequen- 
temente nós selecionamos tanto dramas sociais - de cerimônias nossas ou de outros - ou dramas rituais (ritos de puberdade, cerimônias de casamento, potlaches, etc.), e pedimos aos estudantes para colocá-los em um "enquadramento de cena" ["play frame"] - para relacionar o que estão fazendo ao conhecimento etnográfico do qual precisam cada vez mais, para fazer com que os roteiros que eles usam "façam sentido". Isto os motiva a estudar as monografias antropológicas - e expor lacunas nessas monografias na medida em que elas parecem distanciar-se da lógica da ação e interação dramáticas que eles se propuseram a descrever. A "visão de dentro" do ator, engendrada na e por meio da performance, torna-se uma crítica poderosa de como as estruturas rituais e cerimoniais são representadas cognitivamente (Turner e Turner, 1982, p. 33-34).

Nos últimos anos os Turners encenaram com seus alunos um casamento típico da Virginia, a cerimônia do solstício de inverno dos mohawk do Canadá, o rito de puberdade de uma garota ndembu, e a dança hamatsa das cerimônias sagradas do inverno dos kwakiutl.

De toda esta experiência os Turners chegaram a diversas conclusões interessantes. Eles tornaram-se contra encenar rituais e mitos porque eles "tem sua fonte e raison d'être no fluxo incessante da vida social" e não deveriam ser arrancados aleatoriamente de seus contextos (1982, p. 47-48).

Nossa recomendação, então, é esta: Se nós tentarmos performatizar etnografia, não vamos começar com os fenômenos culturais aparentemente "exóticos" e "bizarros" como rituais e mitos. Tal ênfase pode apenas encorajar preconceitos, pois ela reforça a "outridade do outro". Vamos focar primeiro no que todos os povos compartilham, a forma do drama social, da qual emergem todo tipo de performances culturais, as quais, por sua vez, subitamente estilizam os contornos da interação social da vida cotidiana (1982, p. 48).
Os Turners prosseguem dizendo quão importantes os ensaios são, assim como o compartilhar de determinados alimentos associados com a cultura sob estudo. Claro que eles enfatizam também os balanços: "pelo menos uma sessão deveria ser alocada para fazer uma revisão atenta de todos os aspectos da performance vista em retrospecto" (1982, p. 48). Este é um modo pelo qual o "trabalho de campo" da etnografia performatizada "é escrito" na linguagem mais cognitiva do discurso acadêmico (o seminário, o trabalho de conclusão).

Seria bom ver algumas das ideias de Barba unidas com as ideias dos Turners. Eu quero dizer: Que tal enfatizar não apenas os aspectos cognitivos e experienciais das etnografias encenadas mas também o cinestésico - como o corpo é manuseado, mantido, restringido, liberado? Isto colocaria nos corpos dos estudantes performers um senso vívido do que é se mover "como se" fosse o outro. E isto então envolveria os performers não apenas em ensaios mas em treinamento. No simpósio em Nova Iorque em agosto de 1982 eu percebi a relutância de alguns antropólogos em participar de algumas oficinas que eram parte do programa. No começo de setembro eu tive a experiência de trabalhar diretamente com o shite nô Takabayashi Koji que, junto com diversos outros artistas nô, veio do simpósio de Nova Iorque para a Universidade de Cornell onde ofereceram uma oficina de três dias. Fazer os movimentos do nô concretamente - mesmo que por um período tão breve - ensinou mais ao meu corpo do que páginas de leitura. E mais, quando eu retornei à leitura, aos conceitos como jo-ha-kyu ou ko-shi, eu tive um senso mais firme do que estes conceitos eram. É este tipo de trabalho no-corpo que une os Turners e Barba.

Outros antropólogos têm se interessado por drama. Na Universidade de Chicago McKim Marriott encena um "jogo" com uma de suas classes no qual eles representam o mundo social 
do sistema de castas indiano do modo como ele operaria em uma aldeia. Marriott também encenou em maio de 1982 uma peça folclórica hindi, Rup-Basant (que ele traduziu para o inglês) como parte de sua aula no sul da Ásia. A audiência fez o papel de aldeães indianos. Marriott relata acerca dessa experiência:

Atores foram encorajados a reescrever seus papéis e testá-los em função das respostas da audiência, a audiência já então instruída sobre algumas coisas indianas, e incluindo o instrutor crítico [Marriott], que estava atentando mais para a linguagem corporal realista, estilo hindu. Isto era divertido para quase todo mundo, fez de cada sessão uma surpresa, e deu oportunidades de transmitir uma grande quantidade de informação cultural visceral (1982, m.p.)

Colin Turnbull não apenas trabalhou com Peter Brook em adaptar seu Mountain People para o The Ik, mas também continuou na Universidade George Washington para explorar e relação entre antropologia e drama (ver Garner e Turnbull, 1979). Grotowski esteve há muito interessado em performance intercultural. Seu Polish Laboratory Theater foi um dos primeiros a metabolizar influências não-europeias. Grotowski esteve na Ásia muitas vezes a partir de 1956. Ele também trabalhou com performers estéticos e rituais do Haiti, México, Índia, e outras partes. O trabalho intercultural de Grotowski - incluindo seu último projeto, "drama objetivo" - é discutido no capítulo 5. Todos estes experimentos, e outros que não foram mencionados, são precursores. Os seis "pontos de contato" são pontos nodais altamente carregados que atraem pessoas da antropologia e do teatro. Ao redor desses pontos - que Turner chamaria de campo "liminóide"- está se formando algo intermediário (in-between) e pós-moderno.

Mas porque estes seis pontos de contato específicos e não outros? estes pontos específicos podem não esgotar o que poderia ser definido, mas eles marcam um campo muito concreto e coerente que é de profundo interesse aos teóricos da performance. Quem são os performers, como eles atingem suas transformaçóes temporárias ou permanentes, qual o papel da audiência - estas são as questóes chave, não sobre literatura dramática mas sobre o evento performático vivo ao ser olhado do ponto de vista dos seres humanos envolvidos na performance. Outras questóes podem ser desenvolvidas concentrando-se na cenografia, usos do espaço, vestimentas, objetos cênicos e implementos de performance, e as várias camadas de tecnologia, de bonecos a holografias. Mas a antropologia, como o nome implica, está focada na ação humana; e ainda que estas questóes sejam importantes, e claramente derivem da ação humana, eu estou propondo pontos de contato que podem ser assumidos neste momento, e que me parecem centrais. Os três pontos remanescentes - a sequência total da performance, a transmissão do conhecimento performático, e avaliaçóes - são difíceis de categorizar. Eles constituem áreas particulares de dificuldade dentro do mundo que eu vivo como um diretor de teatro. Em um certo sentido, eu estou buscando ajuda para entender estes processos - uma compreensão holística do sujeito da performance, os meios concretos pelos quais o conhecimento não-literário, não-linear é transmitido, e a relação entre artistas e ritualistas e a sociedade como um todo por eles habitada.

Eu me volto para a antropologia não por ser uma ciência que resolve problemas, mas porque eu percebo uma convergência de paradigmas. Assim como o teatro está se antropologizando, a antropologia está sendo teatralizada. Esta convergência é a ocasião histórica para todos os tipos de trocas. A convergência de antropologia e teatro é parte de um movimento intelectual mais amplo no qual a compreensão do comportamento humano está mudando de diferenças quantificáveis entre causa e efeito, passado e pre- 
sente, forma e conteúdo, etc. (e os modos lineares de análise que explicam tal visão de mundo) a uma ênfase na desconstrução/ reconstrução de atualidades: os processos de enquadramento, edição, e ensaio; o fazer e manipular faixas de comportamento - o que eu chamo de "comportamento restaurado".

Em cada capítulo desse livro eu lido com um ou mais aspectos desses pontos de contato. Eu desloco os problemas que eles evocam reiteradamente. Estou longe de "resolver" qualquer problema. De fato, meu objetivo está mais próximo ao da meditação profunda: uma consideração da complexidade e multivocalidade talmúdica disso, daquilo, e outra permutação do paradigma performático. Nós aceitamos nossa espécie como sapiens e fabricans: aqueles que pensam e fazem. Nós estamos no processo de aprender como humanos também são ludens e performans: aqueles que jogam e performatizam.

\section{Notas}

1. SCHECHNER, Richard. "Ramlila of Ramnagar". In: Between Theatre and Anthropology. Philadelphia: University of Pennsylvania Press, 1985. pp 151-212. [nota da tradutora]

2. Este simpósio foi realizado em Nova Iorque, entre 23 e 31 de agosto de 1982. Foi patrocinado pela Wenner-Gren Foundation for Anthropological Research associada com a American Theatre Association, o Asian Cultural Council, a Asia Society, a International Theatre Institute, e a Tisch School of the Arts, da Universidade de Nova Iorque. O simpósio reuniu praticantes do teatro da Ásia, África, e Euro-América com acadêmicos do teatro e antropólogos. Sessōes incluíram demonstraçôes de treinamento e técnicas de performance bem como discussóes teóricas e históricas. Em Calcutá, India, entre 2 e 11 de janeiro de 1983, realizou-se uma conferência semelhante estudando a relação entre a dança tradicional indiana e o teatro moderno. Delegados da Ásia, Euro-América, América Latina e do Oriente Médio estiveram presentes. Performances e discussôes foram complementadas por muitas demonstraçóes de técnicas variadas de treinamento, oficinas e ensaios. Para uma síntese do encontro em Calcutá, ver Martin e Schechner, 1983.

3. Técnicas de agachamento, temas e o uso único da rua externa ao teatro é discutida em Schechner 1978, 1982b, e no capítulo 7 deste volume. Também Shank e Shank, 1978, e Shank, 1982, p 179-89.

4. SCHECHNER, Richard. "Performers and Spectator Transported and Transformed". In: Between Theatre and Anthropology. Philadelphia: University of Pennsylvania Press, 1985. pp 117-150. [nota da tradutora]

5. SCHECHNER, Richard. "Restoration of Behavior" e "Playing with Genet's Balcony: Looking Back on a 1979/1980 Production”. In: Between Theatre and Anthropology. Philadelphia: University of Pennsylvania Press, 1985. pp 35-116 e 261-294. [nota da tradutora]

\section{Referências bibliográficas}

ANDERSON, Michelle. Authentic Voodoo is Synthetic. Drama Review, New York, v. 26, n. 2, 1982. p. 89-110. BARBA, Eugenio. Theatre Anthropology: First Hypothesis. Transcrição de uma conferência feita em Varsóvia. Distribuída em privado em cópia datilografada. 1980.

Flyer distribuído aos participantes na segunda sessão da International School of Theatre Anthropology, Odin Teatret, Holstebro, Dinamarca. 1981.

. The Way of Opposites. Canadian Theatre Review,

Toronto, v. 35 (summer), 1982. p. 12-37.

. Theatre Anthropology. Drama Review, New York, v. 94 n. 2, 1982a. p. 5-32.

BRECHT, Bertolt. Brecht on Theatre. John Willett (ed.). New York: Hill and Wang, 1964.

BROOK, Peter. On Africa (an interview). Drama Review, New York, v. 17, n. 3, 1973. p. 37-51.

BROWN, Trisha. Three Peaces. Drama Review, New York, v. 19, n.1, 1975. p. 26-32.

GARNER, Natham C.; TURNBULL, Colin M. Anthropology, Drama and the Human Experience. Washington, D. C.: George Washington University, Division of Experimental Programs, 1979.

GEERTZ, Clifford. Blurred Genres. American Scholar, Washington D.C, v. 49, n. 2, 1980. p. 165-182.

GROTOWSKI, Jezy. Towards a Poor Theatre. Holstebro, Dinamarca: Odin Teatret Forlag. 1968.

ISHII, Tatsuro. An Examination into the Mature Thought and Conceptual Framework Presented in the Later Treatises of Zeami. Manuscrito, 1982.

LEX, Barbara W. “The Neurobiology of Ritual Trance”. In: D’AQUILI, Eugene G.; LAUGHLIN JR.; Charles D.; 
236 | RICHARD SCHECHNER

MCMANUS, John. The Spectrum of Ritual. New York: Columbia University Press, 1979.

MARTIN, Carol; SCHECHNER, Richard. Seminars/ Workshops at the Padatik/ITT Calcutta Meetings. January, 1983. Quarterly Journal of the National Centre for the Performing Arts. Bombay, 1983.

MARIOTT, McKim. Carta a Richard Schechner, manuscrito, 1982.

NEARMAN, Mark J. Zeami’s Kyui. Monumenta Nipponica, Tokyo, v. 33, n. 3, 1978. p. 299-331.

PAVIS, Patrice. Languages of the Stage. New York: Performing Arts Journal Publications. 1982.

SCHECHNER, Richard. Drama, Script, Theatre, and Performance. Drama Review, New York, v. 17, n. 3, 1973a. p. 5-36.

Essays on Performance Theory. New York: Drama Book Specialists, 1977.

Anthropological Analysis. Drama Review, New

York, v. 22, n. 3, 1978. p. 23-32.
The End of Humanism. New York: Performing Arts Journal Publications, 1982b.

SHANK, Adele Edling; SHANK, Theodore. Sqaut Theatre's: Andy Warhol's Last Love. Drama Review, New York, v. 22, n. 3, 1978. p. 11-22.

SHANK, Theodore. American Alternative Theatre. New York: Grove Press, 1982.

STANISLAVSKI, Konstantin. An Actor Prepares. New York: Theatre Arts Books, 1946.

VALENCIA, Anselmo. Transcrição de observaçôes feitas em uma Conferência sobre Dança do Cervo Yaqui, patrocinada pela Wenner-Gren Foundation for Anthropological Research, Oracle, Ariz., November, 1981.

VAN GENNEP, Arnold. The Rites of Passage. Chicago: University of Chicago Press, [1980] 1960.

TURNER, Victor; TURNER, Edith. Performing Ethnography. Drama Review, New York, v. 26, n. 2, 1982. p. 33-50.

\section{traduzido de}

SCHECHNER, Richard. "Points of contact between anthropological and theatrical thought". In: Between Theatre and Anthropology. University of Pennsylvania Press, 1985. Copyright Richard Schechner, reprinted with permission. First appeared in Between Theater and Anthropology 1985. University of Pennsylvania Press.

\section{tradutora Ana Letícia de Fiori}

Mestranda em Antropologia Social / FFLCH-USP

revisor

John Cowart Dawsey

Professor / Departamento de Antropologia / USP

revisora Diana Paola Gómez Mateus

Mestranda em Antropologia Social / FFLCH-USP

Recebida em 30/06/2011

Aceita para publicação em 26/09/2011 